\title{
Balancing International Police Cooperation: INTERPOL and the Undesirable Trade-off Between Rights of Individuals and Global Security
}

\author{
Giulio Calcara $^{1}$ \\ Published online: 4 October 2020 \\ (c) The Author(s) 2020
}

\begin{abstract}
With 194 members, INTERPOL is the most influential actor in matters of transnational policing. Regrettably, the organisation is vulnerable against cases of misuse. Certain states manage to exploit the tools of the organisation, to persecute and track political dissidents or non-aligned members of the media outside their borders. As such, INTERPOL has become a prime example on how non-democratic countries can exert their influence and expand their reach well beyond their domestic jurisdictions via their participation in international organisations. Not wanting to allow the proliferation of criminal havens in certain regions, the organisation has opted to connect with and bring together as many police forces of different states as possible. Evidently, such connections are created with little or no consideration of the state of criminal justice systems and forms of government of the countries involved, as well as any subsequent risks. Such a complex state of affairs demands a thorough reflection on whether it is acceptable to compromise between the need for security and the rights of individuals and procedural justice. The issue has vast legal and practical ramifications, and it is ultimately a question pertaining to the realm of global constitutionalism. Does INTERPOL have the legal authority to be in charge of finding a balance between security and procedural justice? If so, on what legal basis, and to what extent?
\end{abstract}

Keywords INTERPOL · Global constitutionalism · Human rights · International organisation $\cdot$ Police cooperation

Giulio Calcara

giulio.calcara@uef.fi

1 Law School, University of Eastern Finland, Joensuu, Finland 


\section{Introduction}

The International Criminal Police Organization (ICPO-INTERPOL), simply known as INTERPOL, is an international organisation which facilitates international police cooperation. ${ }^{1}$ With 194 members, ${ }^{2}$ INTERPOL is the most influential actor in matters of transnational policing with a global reach, and one of the largest international organisations to exist altogether. ${ }^{3}$ Regrettably, the organisation is rather vulnerable against cases of misuse. Certain states have managed to systematically exploit the tools of the organisation, mainly to persecute and track political dissidents or nonaligned members of the media outside their borders. ${ }^{4}$ How misuse can take place in practice is shown through thorough examination of Khadzhiev v. Bulgaria (2014), a case decided by the European Court of Human Rights (ECtHR). ${ }^{5}$ Consequently, INTERPOL has become a prime example on how non-democratic countries can exert their influence and expand their reach well beyond their domestic jurisdictions via their participation in international organisations. ${ }^{6}$

INTERPOL's Rules on the Processing of Data (RPD) allow the organisation to intervene by means of supervision and corrective measures when police forces do not comply with INTERPOL's legal framework. Most notably, according to Articles 17(5), 131 (1) and 131 (3) of the RPD, INTERPOL can ban a state from using its information system. ${ }^{7}$ Yet, it appears that until now INTERPOL has shied away from excluding countries from cooperation processes, even in the face of violations of human rights. This encapsulates the delicate position of the organisation. ${ }^{8}$ Not wanting to allow the proliferation of criminal havens in certain regions, the organisation has opted to connect with and bring together as many police forces of different states as possible. Evidently, such connections are created after little or no consideration concerning the state of criminal justice systems and forms of government of the countries, or the risks involved. ${ }^{9}$ Such a complex state of affairs demands a thorough reflection on whether it is acceptable for the organisation to encourage and allow continuous and uninterrupted police cooperation, at the expense of protection of the rights of individuals and procedural justice. Indeed, it is possible to elaborate the position of INTERPOL as sitting into the centre of a clear dichotomy, where the issue of security is set against procedural justice on a global level. Having realised the existence of such a dichotomy, it becomes clear how all of these aspects present

\footnotetext{
1 Martha (2010a).

2 INTERPOL (2020a).

3 Savino (2010).

${ }^{4}$ Lemon (2019) A thorough research in such matter has been carried out by the NGO Fair Trials. Fair Trials has written several reports and made recommendations to INTERPOL concerning the need for reforms. See: Fair Trials (2020).

5 Case of Khadzhiev v. Bulgaria App No 44330/07 (ECtHR 03/06/2014). The case is available online at: http://hudoc.echr.coe.int/eng\#\{"itemid":["001-144351"]\} (accessed 3 August 2020). See: Calcara (2018).

6 Lemon (2019).

7 Calcara (2018).

8 Calcara (2018).

9 Calcara (2018).
} 
vast legal and practical ramifications, and should be carefully examined in a systematic manner. Two main questions arise: Does INTERPOL have the legal authority to be in charge of finding a balance between security and procedural justice? If so, on what legal basis, and to what extent? Evidently, both questions pertain to the realm of global constitutionalism. ${ }^{10}$

To provide an answer to both questions, this article first analyses INTERPOL as an international organisation, presenting its legal status, structure, and functions. It then discusses INTERPOL's modus operandi, particularly focusing on red notices and diffusions, and on how these tools pose several challenges. The article then explores the complex and multifaceted issue of balancing security and human rights on the international level in the context of international police cooperation, reflecting on the stance that INTERPOL has taken in such a matter.

\section{The Role and Status of INTERPOL}

While INTERPOL is one of the largest international organisations in the world, it is extremely under-researched. ${ }^{11}$ It is no surprise that Sheptycki recently presented INTERPOL as a 'much mythologized and little understood institution.' 12 Among the general public, there are often misconceptions about the legal status of INTERPOL, its membership, legal powers, and role in the international scene.

As of today, INTERPOL is the most important international entity involved in matters of transnational policing and international police cooperation with a global reach. ${ }^{13}$ It possesses a high degree of discretion and power, while at the same time enjoying, perhaps unreasonably, minimal accountability. ${ }^{14}$ To provide a clear picture of INTERPOL and its true nature, this chapter discusses the organisation through four different aspects: legal status and membership, structure, functions, and modus operandi, particularly paying attention to the notices and diffusions systems.

\section{Legal Status and Membership}

Nowadays, a vast number of legal scholars tend to agree on the fact that INTERPOL is, at least formally, an intergovernmental organisation. ${ }^{15}$ This is mainly due to a

\footnotetext{
${ }^{10}$ For a thorough reflection on the field of global constitutionalism, see Tully et al. (2016) and Klabbers et al. (2011).

11 Calcara (2019a).

12 Sheptycki (2017b), 66.

13 Barnett and Coleman (2005) and Sheptycki (2004).

14 Sheptycki (2004).

15 Among many, it is possible to cite few relevant examples: Barnett and Coleman (2005), Boister (2018), Calcara (2020), Hurd (2018), Martha (2010a), Savino (2010), Schöndorf-Haubold (2010), and Sheptycki (2004). For the legal definition of intergovernmental organisation, and the common usage of the terminology relating to international organisations in the context of international institutional law, see Klabbers (2017).
} 
combination of its peculiar legal history, and its role in the international scene. ${ }^{16}$ However, questions concerning the legal status of INTERPOL still elude a straightforward answer. ${ }^{17}$ Indeed, some scholars still view INTERPOL more as a police institution, hence a non-governmental organisation (NGO), rather than a proper intergovernmental organisation. One of the major proponents of this view is Deflem, who has described INTERPOL in these terms:

Although Interpol is an independent police organization and is therefore a non-governmental organization, the organization does collaborate with certain international political and legal bodies. Specifically, Interpol has signed formal agreements of cooperation with the United Nations, the European Union, and the International Criminal Court. ${ }^{18}$

Undoubtedly, INTERPOL possesses a complex history and rather peculiar characteristics which make the organisation difficult to define, and a unicum in the international scene. ${ }^{19}$ In this paragraph, the legal status of INTERPOL is discussed in parallel with its membership, as these are tightly connected to each other, and fundamental to gain a deep understanding of the organisation.

There are two major reasons why the legal status of INTERPOL has been extensively debated.

The first reason concerns the origin of INTERPOL, particularly the fact that it was created unconventionally without a treaty. ${ }^{20}$ The organisation was founded on the 7th of September 1923, in Vienna, at The International Police Congress. ${ }^{21}$ In there, the forerunner of INTERPOL, the International Criminal Police Commission (ICPC), ${ }^{22}$ was formed by way of resolution by a diverse group of police officers from different countries wishing to create a police-centric cooperative institution. ${ }^{23}$ According to the chronicles of the time, avoiding the use of a constitutive treaty appeared to be a deliberate choice, as the delegates of the congress wished to create an international police entity capable of operating transnationally, as free as possible from legal restraints. ${ }^{24}$

During the Second World War, ICPC was hijacked by Nazi authorities. After the war ended, the organisation was reformed and later renamed International Criminal Police Organization (ICPO-INTERPOL). ${ }^{25}$ Since then, several changes have ensued,

\footnotetext{
6 Calcara (2020).

17 A detailed analysis on the controversies concerning the legal status of INTERPOL can be found in the work of Sheptycki (2004). See also: Martha (2010b).

18 Deflem (2016).

19 Calcara $(2019 b, 2020)$.

20 Sheptycki (2004).

21 Deflem (2002a, 2005).

22 Deflem (2002a, 2005).

23 Calcara (2020).

24 Deflem (2008) and Joutsen (2014).

25 Calcara (2020).
} 
but the organisation has remained without a constitutive treaty. Thus, the Constitution of $1956^{26}$ remains as the legal basis of INTERPOL. ${ }^{27}$

The persisting lack of a treaty is indeed highly significant. While the presence of a treaty is not a conditio sine qua non for an entity to be defined an intergovernmental organisation, intergovernmental organisations traditionally have their legal basis in such a legal instrument. ${ }^{28}$

The second reason for uncertainty on the legal status relates to the never truly clarified question of what is the membership of INTERPOL. ${ }^{29}$ The object of debate is in particular whether the states or the domestic police bodies form the membership of the organisation. The reason for such doubts is once again rooted in history. For an extensive period after its creation, INTERPOL appeared to be some sort of private club of policemen. ${ }^{30}$ The 1956 Constitution does not provide much needed clarification with its unusual wording. Article 4 states: 'Any country may delegate as a Member to the Organization any official police body whose functions come within the framework of activities of the Organization. ${ }^{31}$ According to a literal interpretation of this article, police bodies should be considered as the true members of the organisation. However, other articles of the Constitution openly contradict this stance. For instance, Article 4(b) regulates that the request for membership needs to come from an appropriate governmental authority. ${ }^{32}$ Further, according to Article 7 each country can have one delegation head appointed by the competent governmental authority. ${ }^{33}$ At last, Article 45 regulates that those original police bodies of 1956 did not need to apply for a new membership, but it was allowed for their respective governments to withdraw from the Constitution in a six months period of time. ${ }^{34}$ The issue of the membership of INTERPOL was drastically tested inside the organisation in 1984, following a deeply controversial dispute that arose between China and Taiwan. ${ }^{35}$ Through a highly contested and disputed legal and political clash among countries which lead to Taiwan's exit, it became evident that states were, if not de lege at least de facto, the true members of the organisation, at least in the eyes of INTERPOL. ${ }^{36}$

\footnotetext{
26 INTERPOL (2020b).

27 Martha (2010a).

28 Klabbers (2017).

29 Bossard (1988).

${ }^{30}$ Barnett and Coleman (2005). On this matter, Fooner describes in his work the way that INTERPOL was perceived and how it presented itself up to the end of the 80's. Fooner (1989).

31 Constitution of the ICPO-INTERPOL (Interpol's Constitution, as amended) art 4. See the full text of INTERPOL's Constitution at https://www.interpol.int/en/content/download/590/file/Constitution\%20of\%20the\%20ICPO-INTER POL-EN.pdf (accessed 3 August 2020).

32 Interpol's Constitution art 4(b).

33 Interpol's Constitution art 7.

34 Interpol's Constitution art 45.

35 For details of the dispute and how it impacted the issue of membership inside INTERPOL, see Fooner (1989).

36 Martha (2010a).
} 
Considering all the information available on the issue of membership, it is safe to postulate that INTERPOL's membership is constructed at the state level, while being played out through domestic policing institutions. ${ }^{37}$ This argument is corroborated in the next section of the article, when dealing with the structure and complex legal nature of INTERPOL's National Central Bureaus.

Despite the lack of treaty and contradictory norms concerning the membership, it is still reasonable to consider INTERPOL as a true intergovernmental organisation. In search for legitimacy, it was INTERPOL itself who opted to pursue a solidification of its status as an intergovernmental organisation throughout the best part of the second half of the twentieth century. ${ }^{38}$ After managing to being officially recognised as an NGO in 1947 by the UN Economic and Social Council (ECOSOC), ${ }^{39}$ in the early 70's INTERPOL obtained recognition as intergovernmental organisation by several other international organisations and entities. For instance, INTERPOL was referred to as an intergovernmental organisation by the United Nations Secretary General in $1971 .^{40}$ It was recognised as such also by the Customs Co-operation Council and the International Civil Aviation Organisation. ${ }^{41}$ Then INTERPOL concluded several agreements with international organisations and states. ${ }^{42}$ Among these, a series of agreements that INTERPOL signed with France, the country of its headquarter, crystallised its position in the international scene. Particularly, a second agreement signed with France in 1982 granted INTERPOL privileges and full immunities for itself and its staff. ${ }^{43}$ Indeed, having an official headquarter and enjoying international protection for its staff are all crucial characteristics of an intergovernmental organisations. ${ }^{44}$ A year later, the President of the United States enacted Executive Order 12425, which granted INTERPOL with immunities, privileges and exemptions typical of the International Organizations Immunities Act. ${ }^{45}$ This atypical and progressive process of INTERPOL's recognition as intergovernmental organisation, parallel to its emerging role in the international scene, has been aptly defined by Sheptycki as 'customary recognition in international law as Intergovernmental Organisation (IGO). ${ }^{46}$ In the later sections of this article, when analysing the modus operandi of the organisation (e.g. system of notices and diffusions), it is also shown how in the last decades INTERPOL has been repeatedly incorporated in extradition treaties and cooperation treaties with states and international organisations. This can be considered to give additional weight to the previously mentioned opinion of Sheptycki on customary recognition of the legal status of INTERPOL.

\footnotetext{
37 Langille and Megret.

38 Schöndorf-Haubold (2010).

39 Anderson (1989).

40 Anderson (1989), Calcara (2020).

41 Sheptycki (2004).

42 One of the most comprehensive pieces of work on the subject is by Martha (2010a).

43 Calcara (2020).

44 Savino (2010).

45 Fooner (1989) and Sheptycki (2004).

46 Sheptycki $(2004,155)$.
} 
In parallel, and to facilitate its quest to gain status of international organisation, INTERPOL undertook a lengthy process of expansion, legalisation, and internal self-regulation. ${ }^{47}$ Consequently, in the last decades INTERPOL has grown both structurally and functionally, both accruing its legitimacy and reaffirming its position of monopoly in the field of transnational policing at a global level. ${ }^{48}$ Currently, the legal framework of INTERPOL includes: the Constitution of the ICPO-INTERPOL; Financial Regulations; General Regulations; INTERPOL Rules on the Processing of Data; Rules of the Procedure of the Executive Committee; Rules of the Procedure of the General Assembly; Statute of the Commission for the Control of INTERPOL's Files (hereinafter, Statute CCF). ${ }^{49}$

\section{Structure}

The structure of INTERPOL is set in its Constitution. INTERPOL is structured into six different internal bodies: the General Assembly, the Executive Committee, the General Secretariat, the National Central Bureaus, the Advisers, and the Commission for the Control of Files. ${ }^{50}$ The Constitution provides in Articles 6-37 a system of checks and balances to avoid that one body of the organisation would prevail over others. Such a system was ideated after the end of World War II, following the darkest and most controversial period in the history of the organisation. ${ }^{51}$

The General Assembly is the plenary organ of INTERPOL. ${ }^{52}$ It convenes annually, although it can convene for extraordinary sessions. ${ }^{53}$ Among its many functions, which are listed in Article 8 of INTERPOL's Constitution, the General Assembly has the legislative role on the area of competence of INTERPOL. As such, the General Assembly has the power of taking decisions and making recommendations. ${ }^{54}$

The Executive Committee, as the name suggests, acts mainly as the executive body of the organisation. ${ }^{55}$ According to Articles 22(b) and 22 (d) of INTERPOL's Constitution, its main duties are to 'supervise the execution of the decisions of the General Assembly' and 'supervise the administration and work of the Secretary General'. The Executive Committee is composed of a total of thirteen members, each one of them coming from a different state. ${ }^{56}$ Article 21 of INTERPOL's Constitution stresses how the members of the committee are mandated to represent INTERPOL, and not their countries of origin while carrying out their duties.

\footnotetext{
47 Ling (2010a) and Stalcup (2013).

48 Cameron-Waller (2008).

49 INTERPOL (2020c).

50 Interpol's Constitution art 5.

51 Nazi officials managed to completely take over the ICPC to serve their political agenda. The process has been defined as the 'nazification of INTERPOL'. See Deflem (2002b).

52 Savino (2010) and Ling (2010a).

53 Martha (2010a).

54 Interpol's Constitution art 8(f); Ling (2010a).

55 Ling (2010a).

56 Ling (2010a). Interpol's Constitution art 15-16.
} 
The General Secretariat, which is composed by the Secretary General and the technical and administrative staff, is in charge of the day-to-day work of the organisation. ${ }^{57}$ The General Secretariat is the coordinator of all policing and administrative activities of the organisation. It has been active 24/7 since the beginning of the 21th century, and it operates from INTERPOL's headquarters in Lyon. ${ }^{58}$ Unlike many other intergovernmental organisations, INTERPOL has bestowed on its General Secretariat extensive discretional powers. ${ }^{59}$ One of them is the power of initiating cooperation, ${ }^{60}$ which will be highlighted in the modus operandi section of the article when describing the process of INTERPOL issuing notices. As such, the Secretariat carries and supervises most of the activities of INTERPOL, while also operating as a traditional executive body. This rather unique functionality for a General Secretariat can hardly be a coincidence as, in theory, it reinforces the bureaucratic independence of INTERPOL from the political whims of its members on the international scene.

Each of the 194 members of INTERPOL must develop a National Central Bureau (NCB), ${ }^{61}$ which represents the connection point between the state and the organisation. ${ }^{62}$ Interestingly, these are peculiar entities in international law. They operate as extension of INTERPOL, while being under the domestic law of their respective countries. ${ }^{63}$ To be more specific, National Central Bureau are not obliged to comply or enforce directives of INTERPOL, but they are bound to their domestic laws and domestic policing institutions. ${ }^{64}$ As a consequence, one of the most complex issues is to define to whom National Central Bureaus belong to, in particular whether they are bodies of INTERPOL, or property of the state which developed them. According to Martha, the answer lies somewhere in the middle; the NCBs are part of both the states which created them, and of the organisation. ${ }^{65}$ Contrary to this, in the early eighties the United States Court of Appeals, District of Columbia Circuit identified the US National Central Bureau as belonging exclusively to the United States. ${ }^{66}$ While it is on its own a topical question of international institutional law, the question concerning to whom NCBs belong to, is indeed of utmost importance for several reasons, ${ }^{67}$ including for the purpose of clarifying accountability matters. ${ }^{68}$

\footnotetext{
57 Interpol's Constitution art 27.

58 INTERPOL (2020d).

59 For the traditional powers of the different bodies of intergovernmental organisations, see e.g.: Klabbers (2015).

60 Calcara (2018).

61 Martha (2010b).

62 Interpol's Constitution art 32; Sheehan (2012).

63 Savino (2010).

64 Sheptycki (2004).

65 This is a highly specific condition, potentially giving rise to extremely complex legal consequences, defined as dedoublement fonctionnel. It has been explored in great detail in the works of Martha. See: Martha (2010a, b).

66 See: Founding Church of Scientology v. Regan (1981) 670 F.2d 1158.

67 Calcara (2018).

68 Calcara (2018)
} 
The Advisers are individuals that assume an advisory function for INTERPOL on scientific matters. ${ }^{69}$ They are appointed by the Executive Committee for a threeyear term. Their appointment becomes definitive after notification from the General Assembly. The General Assembly can remove them from office by way of decision. $^{70}$

The Commission for the Control of INTERPOL's files is the most recent body of INTERPOL, having only been established in $2008 .{ }^{71}$ It is an independent entity in charge of ensuring the compliance of the processing of data with INTERPOL's regulations. On this matter, it provides the organisation with advice, and is in charge of processing all requests dealing with the information stored in INTERPOL's database. $^{72}$

\section{Functions}

Article 2 of INTERPOL's Constitution defines the aims of the organisation, which are:

1) To ensure and promote the widest possible mutual assistance between all criminal police authorities within the limits of the laws existing in the different countries and in the spirit of the "Universal Declaration of Human Rights"

2) To establish and develop all institutions likely to contribute effectively to the prevention and suppression of ordinary law crimes.

The first scope of INTERPOL is thusly to champion direct mutual assistance among different police institutions on a global level. This is something not to be underestimated, as INTERPOL has contributed to a historical shift in the traditional way of cooperation in police matters. With the advent of INTERPOL, cooperation has in fact been directly put into the hands of domestic police institutions, bypassing the traditional diplomatic channels which were traditionally in charge until the early 20th century. ${ }^{73}$ This in turn caused the shift from a traditional state-centric way of international cooperation, to a police-centric one. Needless to say, avoiding the diplomatic route in matters of cooperation has meant removing obstacles of both time and political character. ${ }^{74}$ On the other hand, direct and continuous communication among police institutions of countries with different legal traditions and criminal justice systems ${ }^{75}$ has caused, and continues to pose, serious practical and legal

\footnotetext{
${ }_{69}$ Interpol's Constitution art 34.

70 Interpol's Constitution art 35.

71 Ling (2010b).

72 Interpol's Constitution art 36; Statute of the Commission for the Control of INTERPOL's Files (Statute CCF, as amended) II.E/RCIA/GA/2016 art 3. See the full text of the Statute of the Commission for the Control of INTERPOL's Files athttps://www.interpol.int/en/content/download/5695/file/Statute\%20 of\%20the\%20CCF-EN.pdf (accessed 3 August 2020).

73 Andreas and Nadelmann (2006).

74 Andreas and Nadelmann (2006).

75 Savino (2010).
} 
challenges. ${ }^{76}$ According to Article 2(2), INTERPOL needs to also provide assistance and support to all institutions involved in the fight against transnational and international crime. ${ }^{77}$ INTERPOL has interpreted this article broadly, being also involved in interacting with different actors besides only police institutions. A good example is the involvement of INTERPOL in the world of sports, the INTERPOL-FIFA Initiative. In this project, INTERPOL has been involved in the development of strategies to address and counteract the virulent issue of match fixing in football. ${ }^{78}$

In order to fulfil its mandate expressed in Article 2 of the Constitution, INTERPOL has planned its activities around four main areas, dubbed as 'core functions' ${ }^{79}$ These are: secure global police communications services; operational data services and databases for police; operational police support services; and training. ${ }^{80}$ The first three functions are all at least partly related to different aspects of the exchanging of information at various levels through INTERPOL. They range from the development of security in the context of police communication, to the modalities of exchange and production of criminal intelligence. ${ }^{81}$ The fourth function focuses on capacity building of police institutions, notably the NCBs. ${ }^{82}$

The Constitution of INTERPOL sets tight limits for the organisation. According to Article 2(1), mutual assistance endorsed by INTERPOL must happen within the boundaries set by the laws of member countries and in the spirit of the Universal Declaration of Human Rights. This is a rather unusual formula in international institutional law, ${ }^{83}$ as it implies that INTERPOL, and police institutions working through the organisation, are not meant to act according to the will and the laws of the member countries, instead, they maintain power and full discretion up until the point where a law is overtly violated. ${ }^{84}$ The ratio behind this provision can partly be derived from the original spirit of INTERPOL of creating a police-centric system of cooperation. ${ }^{85}$ With this same spirit, the ICPC, and later the modern INTERPOL, was formed without the aid of a treaty to shield (perhaps naively) the organisation from legal obligations. ${ }^{86}$

The Constitution of INTERPOL sets another limit for the organisation. While carrying its activities, INTERPOL has to maintain neutrality. ${ }^{87}$ This is specifically set in Article 3: 'It is strictly forbidden for the Organization to undertake any intervention or activities of a political, military, religious or racial character.' The

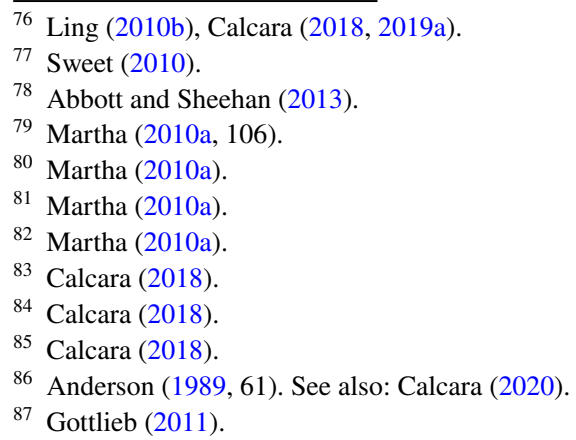


interpretation of Article 3 has drastically changed over time. ${ }^{88}$ Interpretation of this article has compressed and expanded both the range of activities that INTERPOL could undertake, and the type of crime areas that INTERPOL could tackle. ${ }^{89}$ For instance, the interpretation of Article 3 has changed INTERPOL's relation with the crime area of terrorism. ${ }^{90} \mathrm{Up}$ until the 70 's, the organisation was avoiding involvement to cases of terrorism, as they were considered by definition to be 'political' in nature. Particularly enlightening of INTERPOL's firm position on the matter, is the organisation refusal in 1972 in aiding and forwarding requests for cooperation coming from the West Germany NCB following the infamous Munich Massacre, the terrorist attack at the Olympics that costed the lives of Israeli athletes. ${ }^{91}$ The reason for such refusal were grounded in a strict interpretation of Article $3 .{ }^{92} \mathrm{Gradu}-$ ally since the 80's, and then gaining momentum after 9/11, INTERPOL modified its approach. As of now, the organisation considers all forms of terrorism to fall within its mandate, and provides a platform to allow police forces to actively cooperate in this field, ${ }^{93}$ and since 2017, INTERPOL has defined 'counter the threat of terrorism' as its first goal in its 'global policing goals' agenda. ${ }^{94}$ As might be expected, the interpretation of Article 3, and the subsequent choice of expanding or compressing the range and content of INTERPOL's activities, is at times motivated by political or practical considerations, rather than legal ones. ${ }^{95}$

As of late, INTERPOL is especially active in 18 crime areas of different nature. ${ }^{96}$

\section{Modus Operandi: Notices and Diffusions Systems}

While INTERPOL has been developed with the aim of addressing the previously mentioned four core functions 'secure global police communications services', 'operational data services and databases for police', 'operational police support services', and 'training', what is most relevant for the scope of this article is the study of INTERPOL's modus operandi concerning the exchange of criminal data and police information sensu lato. As such, the focus of analysis will only concern the modus operandi of the organisation, covering a part of the first three core functions. The reason behind this choice rests on the fact that the exchange of criminal data

\footnotetext{
${ }^{88}$ An excursus on the different historical interpretations of Article 3 is provided by INTERPOL. INTERPOL (2013).

89 INTERPOL (2013).

90 Gerspacher (2008).

91 Barnett and Coleman (2005) and Calcara (2020).

92 Interestingly, such obstinacy of INTERPOL in abstaining from operating in terrorist cases appears to be one of the reasons why so many other systems and bodies of police and judicial cooperation flourished in Europe in the following years. Bigo (2000).

93 Deflem (2002a, 113, 2006, 2010), and Sandler et al. (2011).

94 INTERPOL (2017).

95 Barnett and Coleman (2005).

96 Higgins and White (2016, 103). See also: Kind (2011), and Calcara (2013).
} 
and police information is ultimately the main raison d'être for INTERPOL, as well as being the type of activity, which poses the most urgent legal challenges. ${ }^{97}$

The General Secretariat, together with the National Central Bureaus (NCBs), are the key bodies of INTERPOL involved in the exchange of data. ${ }^{98}$ NCBs can communicate either directly with each other, or through the General Secretariat, which essentially works as a central hub for cooperation. INTERPOL's communications system is the I-24/7 network. ${ }^{99}$ It is a sophisticated information system, which allows cooperation to be conducted in real-time, in a secure manner, and around the clock. ${ }^{100}$ Through this system, authorised users and domestic police forces can also get immediate access to the databases of the organisation. ${ }^{101}$ Operations concerning the exchange of data are regulated by the RPD, a set of rules which were approved in the end of 2011, and entered into force in the end of June 2012 (with the exception of some articles which entered into force a year later). They adhere to the general common principles of data protection laws, such as the ones of proportionality and purpose limitation. ${ }^{102}$ The rules have been subsequently amended several times. ${ }^{103}$

INTERPOL provides its members several tools to facilitate cooperation. Arguably, the most renowned is the system of notices. ${ }^{104}$ INTERPOL has made use of this system for several decades, at least since 1946, albeit in different forms, and limited by the technology of each historical period. ${ }^{105}$

As specified in Article 1 (13) of the RPD, with notices INTERPOL refers to a specific kind of request for international cooperation or international alerts. Notices are published by the organisation, following a request of a National Central Bureau, an authorised international entity, or by direct initiative of the General Secretariat, and are circulated among all the members of the organisation. There are various categories of notices, and most are differentiated by a distinct colour for highlighting their specific content. ${ }^{106}$ Red notices are published for seeking the location, detention, arrest, or restriction of movement of a wanted person to obtain extradition,

\footnotetext{
97 However, for the sake of clarity, it should also be pointed out that the development of the fourth function was not entirely void of controversy, since the Constitution of INTERPOL does not explicitly mention this function in the mandate of the organisation. As such, the development of the fourth core function can be reconnected to the well-known doctrine of implied powers of international organisations. Martha (2010a), 124.

98 Calcara (2018).

99 Stalcup (2013).

100 INTERPOL (2020e).

101 INTERPOL $(2020 \mathrm{e})$.

102 Martha (2010a, b) and Ling (2010a) and Calcara (2019). This is particularly notable in the requirements of quality, lawfulness of data, and purpose-specificity. De Hert and Saifert (2018).

103 Calcara (2019b). Interestingly, the enactment of these rules can be seen as representing part of that internal process of self-regulation and legalisation undertaken by INTERPOL to solidify its legitimacy in the international scene. Studies on INTERPOL's expansion, both structurally and functionally, and its quest for achieving legitimacy have been conducted by several scholars, such as Barnett and Coleman (2005), Ling (2010a, b), Sheptycki (2004), and Stalcup (2013).

104 Deflem (2016).

105 Fooner (1989).

106 Deflem (2016) and INTERPOL (2020f).
} 
surrender, or similar act. ${ }^{107}$ Blue notices are published in order to gather information concerning the identity, location, or activities of a person of interest in the context of a crime. ${ }^{108}$ Green notices are published to put out an alert about the criminal activities of a person, in case the person is to be considered a possible threat to public safety. ${ }^{109}$ Yellow notices are published in order to locate a missing person, or for the purpose of identifying a person unable to provide identification. ${ }^{110}$ Black notices are published to retrieve information for the purpose of identifying dead bodies. ${ }^{111}$ Purple notices are published for seeking or providing information about criminal modus operandi, objects, devices, and concealment methods. ${ }^{112}$ Orange notices are published to raise awareness concerning an event, a person, an object, or a process, which has potential of posing a threat. ${ }^{113}$ Stolen work of art notices are published to locate stolen objects of artistic value, or to seek information on similar items retrieved under suspicious circumstances. ${ }^{114}$ The INTERPOL-United Nations Security Council Special Notices are published to alert the members of INTERPOL about entities and individuals subject to sanctions of the UN Security Council. ${ }^{115}$ Lastly, INTERPOL's internal regulations include the possibility of creating new kinds of notices to allow cooperation with a private entity, following an agreement between INTERPOL and that entity. These notices are defined as special notices. ${ }^{116}$ It should be noted that the red and blue notices are the most commonly used. ${ }^{117}$

There are certain legal requirements to be met for the publication of notices. On this matter, Article 73(3) RPD states that the RPD provides conditions for publishing for each category of notices. These conditions can reflect the general conditions for recording of data in INTERPOL, which are established in Articles 35, 37-44, and 97 of the RPD, or they can be more restrictive. ${ }^{118}$ In both cases, the content of the regulation concerning the processing of data in INTERPOL's databases adheres to common principles of data protection laws, such as proportionality and purpose limitation. ${ }^{119}$

\footnotetext{
107 INTERPOL's Rules on the Processing of Data (RPD, as amended), III/IRPD/GA/2011 art 82. See the full text of the INTERPOL's Rules on the Processing of data at https://www.interpol.int/en/conte nt/download/5694/file/24\%20E\%20RPD\%20UPDATE\%207\%2011\%2019_ok.pdf (accessed 3 August 2020).

108 RPD art 88.

109 RPD art 89.

110 RPD art 90.

111 RPD art 91.

112 RPD art 92.

113 RPD art 93.

114 RPD art 94.

115 RPD art 95. This kind of notice was created following the implementation of a resolution of the United Nations Security Council: UNSC Res 1617 (29 July 2005). See: Schöndorf-Haubold (2010).

116 RPD art 28 and 96.

117 Deflem (2016).

118 Calcara (2019b).

119 Calcara (2019b), Martha (2010a), de Hert and Saifert (2018).
} 
Another important part of the modus operandi of INTERPOL, is the diffusions system. The system provides a less formal way of activating cooperation through INTERPOL, if compared to the notices system. ${ }^{120}$

According to Article 97 RPD, the diffusions system 'consists of standardized requests for cooperation and alerts each corresponding to a specific purpose.' The rather limited amount of conditions for circulating diffusions through INTERPOL's information system are set in Article 99 RPD. The article sets a duty for the NCB or the authorized international entity circulating a diffusion to adhere to the general requirements of quality and lawfulness concerning the data supporting the diffusion. Additionally, there is a duty to ascertain that the diffusion is in compliance with the general conditions for the recording of data in INTERPOL's information system, that the data in the diffusion is relevant for the purpose of international police cooperation and in line with INTERPOL's rules and international law. ${ }^{121}$

Significantly, diffusions do not have to pass through an initial check of the General Secretariat prior to publication. ${ }^{122}$ Yet, since 2016, all diffusions dealing with wanted persons undergo a review process carried out by a quality-control team in INTERPOL. ${ }^{123}$ However, NCBs or an authorized international entity can send diffusions to one or more NCB or an authorized international entity, autonomously.

\section{Political Abuse of INTERPOL's Red Notices and Diffusions}

Due to INTERPOL's extensive membership, cooperation inside the organisation takes place among police forces belonging to countries of diverse legal traditions, with very different criminal justice systems. That on its own can be the source of extremely complex legal issues. ${ }^{124}$ For instance, various types of judicial documents, arrest warrants, and police tips are often enforced in countries where they should not be recognised as valid due to irreconcilable differences in criminal law or procedural law. ${ }^{125}$ Interestingly, this is one of the main reasons why some legal scholars tend to view the increasing cooperation in police matters as an assault to the sovereignty of states. $^{126}$

Even more worrisome, there are instances where the tools of INTERPOL are misused, if not abused, due to controversial behaviour of the members of the organisation and the actions of the respective NCBs. ${ }^{127}$ Naturally, in using such a system human error can occur, but, unfortunately, behind many cases of misuse there are often sinister motives. $^{128}$

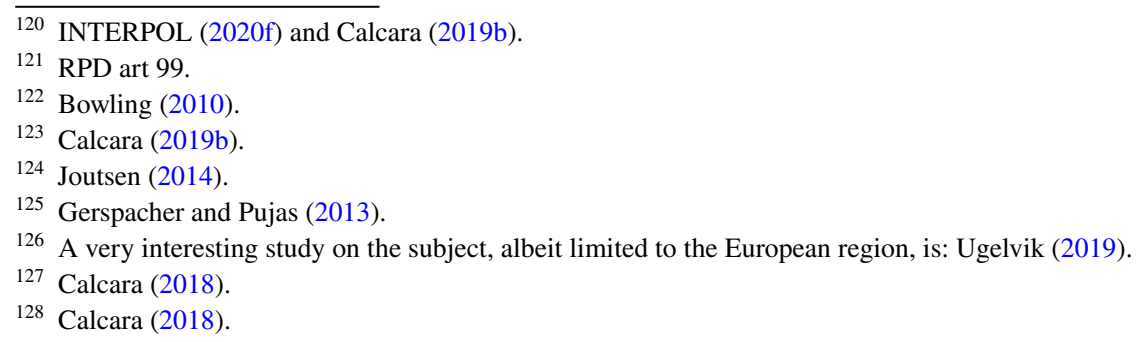


Several authoritarian countries have managed to successfully exploit INTERPOL's tools for the purpose of advancing their own political agendas. It is still a surprisingly common phenomenon for political dissidents or members of the media to be targeted through distorted use of the notices and diffusions systems. ${ }^{129}$

Before providing an analysis on how and why misuse happens and on what types of countermeasures are adopted by INTERPOL, it is essential to take a step back and reflect on the very nature of the system of cooperation promoted by INTERPOL, and in particular the way red notices and diffusions are structured. The way the red notices and diffusions are designed and implemented make misuse not only possible, but inevitable.

\section{Analysing the Legal Effects of Red Notices and Diffusions}

As of today, a red notice is a sui generis tool of transnational policing, in many aspects comparable to an international arrest warrant. ${ }^{130}$

While the nature of red notices is undoubtedly administrative, their legal effects might not be. ${ }^{131}$ Red notices are in fact used for obtaining detention, arrest, or restriction of movement of individuals for the purpose of extradition, surrender, or similar action. ${ }^{132}$ Article 87 RPD provides some procedural guidelines to be followed, whenever an individual subject of a red notice is located:

Article 87: Steps to be taken following the location of the person If a person who is the subject of a red notice is located, the following steps shall be taken:

(a) The country where the person has been located shall:

(i) immediately inform the requesting National Central Bureau or international entity and the General Secretariat of the fact that the person has been located, subject to limitations deriving from national law and applicable international treaties;

(ii) take all other measures permitted under national law and applicable international treaties, such as provisionally arresting the wanted person or monitoring or restricting his/her movement.

(b) The requesting National Central Bureau or international entity shall act immediately once it has been informed that the person has been located in another country and, in particular, shall ensure the swift transmission - within the time limits defined for the case in question - of data and supporting documents requested by the country where the person was located or by the General Secretariat.

\footnotetext{
129 Lemon (2019).

130 Bassiouni (2014) and Langille and Mégret (2018).

131 Savino (2010).

132 RPD art 82.
} 
(c) The General Secretariat shall provide assistance to the relevant National Central Bureaus or international entities by, inter alia, facilitating the transfer of documents related to the provisional arrest or the extradition procedures in accordance with the relevant national laws and international treaties.

Being subject to domestic law, there is no absolute legal obligation for INTERPOL's member states to enforce red notices to their full extent. ${ }^{133}$ However, a large number of international treaties and agreements consider INTERPOL a legitimate tool for circulating various types of judicial requests, including provisional arrests for the purpose of extradition. ${ }^{134}$ Two prime examples are the European Convention on Extradition ${ }^{135}$ and the ECOWAS Convention on Extradition. ${ }^{136}$ There are also other types of international agreements, signed directly between INTERPOL and various international entities, such as international courts or tribunals, which may include the use of red notices, like the Co-operation Agreement between the Office of the Prosecutor of the International Criminal Court and the International Criminal Police Organization. Agreements, such as this one, directly increase the legal effects and the binding nature of red notices. For instance, Article 4 of the agreement states:

Article 4 Publication and circulation of Interpol notices

1. The ICC-OTP shall have the right to request the Interpol General Secretariat to publish and circulate to National Central Bureaus (NCBs) Interpol notices of all types for the facilitation of inquiries: the red notices for the circulation of details of persons sought by the ICC-OTP and for preventing such persons from escaping prosecution; the blue notices for obtaining supplementary information, for instance on perpetrators or key witnesses; the yellow notices for tracing missing persons; and the black notices for facilitating identification of corpses. ... ${ }^{137}$

\footnotetext{
133 Bowling (2009).

134 Calcara (2019b).

135 European Convention on Extradition (adopted 13 December 1957, entered into force 18 April 1960) ETS No 24 (European Convention on Extradition). The text of the convention is available online at: https ://www.coe.int/en/web/conventions/full-list/-/conventions/rms/0900001680064587 (accessed 3 August 2020).

136 Economic Community of West African States Convention on Extradition (adopted 6 August 1994) A/P.1/8/94 (ECOWAS Convention on extradition). The text of the convention is available online at: http://documentation.ecowas.int/download/en/legal_documents/protocols/Convention\%20on\%20Extradit ion.pdf (accessed 3 August 2020). See: Calcara (2019b).

137 Co-operation Agreement between the Office of the Prosecutor of the International Criminal Court and the International Criminal Police Organization (enacted 22 March 2005, entered into force 22 March 2005) art 4. The entire text of the agreement can be seen at: https://www.interpol.int/content/downl oad/11060/file/4-\%20ICC.pdf (accessed 3 August 2020).
} 
Additionally, if Part 9 of the Rome Statute of the International Criminal Court ${ }^{138}$ is taken into account, it becomes clear that in case the Office of the Prosecutor of the International Criminal Court (ICC-OTP) would ask and obtain the issuing of an INTERPOL notice, and the notice would be in accordance to the relevant provisions of the ICC Statute, all countries belonging to both INTERPOL and the ICC would be obligated to enforce such a notice to its full extent. ${ }^{139}$

Partly for all the above reasons, red notices are currently enjoying a high degree of compliance. ${ }^{140}$ However, it is paramount to clarify that even when not supported by other international instruments, several states and various international entities hold red notices in high regard. Indeed, around one-third of the members of INTERPOL recognise a red notice as sufficient grounds for making a provisional arrest. ${ }^{141}$ Further, in certain instances, a red notice has been inappropriately used to justify lengthy periods of detention. This is best shown in Khadzhiev v. Bulgaria (2014), a case decided by the ECtHR. ${ }^{142}$ In this case, Mr. Khadzhiev tried to appeal his detention in Bulgaria, which he deemed unlawful. He was arrested due to a red notice issued by INTERPOL at the request of Turkmenistan. In paragraph 36, it is possible to see the justification for his detention provided by the Varna Court of Appeal:

The court stated that it could not review whether sufficient evidence had been collected to prove the applicant's guilt or whether the alleged crime was identical to the one examined during the extradition proceedings in 2003. However, in its view, the fact that the applicant was wanted by Interpol was sufficient to justify his detention. As a result, the court upheld the regional court's judgment. $^{143}$

138 Rome Statute of the International Criminal Court (adopted 17 July 1988, entered into force 1 July 2002) 2187 UNTS 90 (ICC Statute) art 86-87:

PART 9.INTERNATIONAL COOPERATION AND JUDICIAL ASSISTANCE

Article 86. General obligation to cooperate

States Parties shall, in accordance with the provisions of this Statute, cooperate fully with the Court in its investigation and prosecution of crimes within the jurisdiction of the Court.

Article 87. Requests for cooperation: general provisions

1. (a) The Court shall have the authority to make requests to States Parties for cooperation. The requests shall be transmitted through the diplomatic channel or any other appropriate channel as may be designated by each State Party upon ratification, acceptance, approval or accession. Subsequent changes to the designation shall be made by each State Party in accordance with the Rules of Procedure and Evidence.

(b) When appropriate, without prejudice to the provisions of subparagraph (a), requests may also be transmitted through the International Criminal Police Organization or any appropriate regional organization. ...

The entire text of the ICC Statute can be seen at: https:/www.icc-cpi.int/resource-library/Documents/ RS-Eng.pdf (accessed 3 August 2020).

139 This obligation would be in accordance with the general principles of cooperation between ICC and state parties. See: Cassese (2013).

140 Savino (2010).

141 Langille and Mégret (2018).

142 While other cases could have been chosen to illustrate this type of abuse, this case has the merit of having been judged by an international court dealing with human rights. Hence, it is of significant relevance to the analysis in the context of this article. See also Calcara (2018).

143 Case of Khadzhiev v. Bulgaria App No 44330/07 (ECtHR 03/06/2014) 36. 
In general, it appears that several states tend to adopt a 'better safe than sorry' approach in matters of security. So much so that individuals have been arrested in certain instances even when their identity was only connected to a blue notice, a disproportionate reaction clearly at odds with the spirit of INTERPOL's RPD. ${ }^{144}$

INTERPOL took a stance on the approach that members should have when dealing with a red notice by enacting a resolution, which clearly reinforces automatic enforcement of red notices:

The ICPO-INTERPOL General Assembly ... CALLS UPON all National Central Bureaus, if permitted under their national laws and in accordance with applicable international treaties, to take the necessary steps to encourage the appropriate authorities in their countries to recognize the red notice as a valid request for provisional arrest pending extradition or to enable similar lawful actions to be taken on the basis of a red notice. ${ }^{145}$

The resolution was adopted during INTERPOL's 80th General Assembly, the same General Assembly where the INTERPOL's RPD were approved. ${ }^{146}$ The RPD being the latest regulation on the subject, it is safe to assume that the operative clause is still relevant.

While diffusions are considered a less formal way of activating cooperation, they enjoy a similar degree of compliance. ${ }^{147}$ This means that an individual, whether subject of a red notice or a diffusion of similar content, will incur a high chance of suffering an arrest, a period of detention, or restriction of movement for the purpose of extradition, surrender, or similar action. ${ }^{148}$

Summarising, the enforcement of both red notices and diffusions is left to the discretion of the members of INTERPOL, as in theory neither document type is meant to produce autonomous and direct legal effects. With red notices, there are specific instances where they can possess legal effect due to being connected to pre-existing obligations arising from domestic or international law. That is, for instance, if they are mentioned in specific international treaties among states, or in specific agreements within INTERPOL and other international entities, such as the ICC. De facto, both red notices and diffusions are used and recognised by several countries as if they are international arrest warrants, regardless whether or not they are backed up by additional legal documents.

\footnotetext{
${ }^{144}$ Ling (2010b).

145 INTERPOL 'The red notice system' Res AG-2011-RES-06 (31 October-3 November 2011) 2. The resolution is available online at:

https://www.interpol.int/content/download/6057/file/AG-2011-80-RES-06\%20-\%20The\%20red\%20not ice\%20system\%20.pdf (accessed 3 August 2020).

146 Calcara (2019b).

147 Marino and Grantham (2015).

148 Marino and Grantham (2015).
} 


\section{How and Why Authoritarian Countries Abuse INTERPOL's Red Notices and Diffusions}

There have been several instances where countries have wrongfully accused individuals of crimes in order to manipulate INTERPOL into issuing red notices. ${ }^{149}$ It should be noted that not all attempts to misuse the information system are successful. For example, in 2016, INTERPOL denied 60.000 requests for red notices initiated by Turkey, following the alleged coup d'état. ${ }^{150} \mathrm{In}$ fact, prior to issuing each notice, the General Secretariat of INTERPOL has to perform a review. In particular, according to the Article $86 \mathrm{RPD}$, when it comes to red notices, a more advanced legal review is required:

Article 86: Legal review by the General Secretariat

The General Secretariat shall conduct a legal review of all red notices prior to their publication to ensure compliance with INTERPOL's Constitution and Rules, in particular with Articles 2 and 3 of INTERPOL's Constitution. ${ }^{151}$

However, the legal review can only work up to a certain extent. At times, countries have gone as far as producing fictional criminal evidence to back up illegitimate judicial documents, in order to convince and pressure INTERPOL into issuing a red notice. ${ }^{152}$ This is what happened in the case of Khadzhiev v. Bulgaria (2014). In the court proceedings, it was shown that Turkmenistan accused Mr. Khadzhiev of embezzling public funds. ${ }^{153}$ According to the judicial authorities of Turkmenistan, the crime was committed between 25 July and 3 September, 2002. The evidence for such allegations relied heavily on the fact that Mr. Khadzhiev committed the offence while being an official at the Central Bank of Turkmenistan. This was, however, impossible since Mr. Khadzhiev stopped working in the bank in 1998. ${ }^{154}$ Obviously, in cases such as this one, it is hard for INTERPOL to evaluate the legitimacy of a request during the first review stages. In order to do so, INTERPOL should be able to thoroughly assess the legitimacy of the processes and the quality of the criminal justice systems of its own members, and, as it will be discussed later, that would be extremely problematic to achieve.

In cases where INTERPOL refuses to publish a red notice, it should be taken into account that countries are still able to circulate, and do circulate, diffusions autonomously through the system. ${ }^{155}$ As mentioned in the previous paragraph, they enjoy a similar degree of compliance. This is best exemplified by the case of Mr. Browder, a

\footnotetext{
${ }^{149}$ A new study of the European Parliament mentions several recent cases of misuse. The title of the study is: 'Misuse of Interpol's Red Notices and impact on human rights-recent developments'. See https://www.europarl.europa.eu/RegData/etudes/STUD/2019/603472/EXPO_STU(2019)603472_ EN.pdf (accessed 3 August 2020). European Parliament (2019). On this issue see also: Both (2002).

150 Lemon (2019).

151 RPD art 86.

152 Calcara (2018).

153 The alleged embezzlement amounted to 40,000,000 United States dollars. Calcara (2018).

154 Calcara (2018).

155 See: Bromund (2019a).
} 
U.S.-born U.K. banker and a "high profile critic" of the Russian President Putin, ${ }^{156}$ famous for championing the enactment of the Russia and Moldova Jackson-Vanik Repeal and Sergei Magnitsky Rule of Law Accountability Act of 2012 (Magnitsky act). The Magnitsky act is a US law meant to punish those responsible for the death of the lawyer of Mr. Browder, Mr. Magnitsky, in a Russian jail in 2009. ${ }^{157}$ From 2013, Russia requested INTERPOL on a number of occasions to issue a red notice against Mr. Browder as he was found to be guilty of tax evasion by Russian courts. ${ }^{158}$ INTERPOL denied all the requests of Russia to publish a red notice, as all the requests were deemed by the organisation to be political in nature. However, Russia proceeded and managed to issue a diffusion against Mr. Browder, which was then deleted by INTERPOL. ${ }^{159}$

According to Lemon, there are both punitive and political reasons why authoritarian countries misuse INTERPOL's tools, particularly the system of notices. ${ }^{160}$ The punitive reasons are self-evident. Red notices and diffusions generally cause intense distress to individuals sought after. For instance, once a red notice is published, the individual subject of the notice incur the risk of getting arrested in any given state that is a member of INTERPOL. ${ }^{161}$ This distress is exacerbated by the fact that since an INTERPOL red notice is published by INTERPOL, only INTERPOL has the power to delete that notice, either of its own initiative, or at the request of the original source. ${ }^{162}$ This means that if the individual is arrested in a state, and then released once it becomes apparent that the red notice is based on wrongful premises, the same individual can still be arrested if travelling to another state. ${ }^{163}$ However, being subject to a red notice does not only cause a loss of freedom of travelling. It can be the source of several other kinds of distress as well, including the loss of ability to rent properties, to open bank accounts, to search for jobs etc. ${ }^{164}$ Additionally, there can be significant reputational damage if the red notice is disclosed to the public and advertised on INTERPOL's website. ${ }^{165}$ Ironically, in case the red notice is not disclosed to the public, other equally damaging side effects can happen. For instance, an individual might not be aware to be on INTERPOL's database ${ }^{166}$ and thusly potentially suffer an unexpected arrested when entering into a state.

\footnotetext{
156 BBC (2018).

157 Lemon (2019) and Bromund (2019b). Interestingly, the Magnitsky act was then used as a basis for the U.S. Global Magnitsky Act (GMA). The latter is a US law meant to address and allow sanctions for foreign individuals or entities involved in abuse of human rights or large scale corruption. Firestone and Contini (2018).

158 Lemon (2019) and Bromund (2019b).

159 Bromund (2019b). In 2018 Browder was arrested in Spain on the basis of a Russian arrest warrant, and immediately released. While Browder claimed through the Twitter platform that he was wanted due to a"Russian Interpol arrest warrant", hinting perhaps at a red notice, the organisation claimed that no red notice had ever been issued against him. BBC (2018).

160 Lemon (2019).

161 Lemon (2019).

162 RPD art 81.

163 Savino (2010).

164 Lemon (2019).

165 Tinsley (2017).

166 Lemon (2019).
} 
Political reasons can be connected to why states might wish to boost their own propaganda machines: publicising that an individual is wanted by INTERPOL, they can claim that there is a global condemnation towards their own dissidents. ${ }^{167}$ Needless to say, this is obviously a misleading proposition, and certainly contrary to the spirit of INTERPOL's regulations. ${ }^{168}$

\section{Legal Safeguards of INTERPOL Against the Misuse of the Notices and Diffusions Systems}

INTERPOL is equipped with a number of internal legal safeguards to prevent and counteract the misuse of the notices and diffusions systems. ${ }^{169}$ These legal safeguards are regulated in various parts of INTERPOL's legal framework, namely in the RPD, and the Statute CCF. ${ }^{170}$

In the RPD, some preventative legal safeguards are listed. The red notices enjoy the most encompassing one, the previously mentioned pre-publication mandatory legal review to be undertaken by the General Secretariat, as prospected in Article 86 RPD. Instead with diffusions, there is no mandatory legal review. ${ }^{171}$ However, diffusions that deal with wanted persons still undergo a review process performed by a quality-control team in INTERPOL. ${ }^{172}$

Safeguards meant to counteract cases of misuse are also regulated in the RPD. For instance, the General Secretariat of INTERPOL has the power to cancel notices. The grounds for cancellation are listed in Article 81(3):

The General Secretariat shall cancel a notice if:

(a) the purpose of the cooperation request or the alert on the basis of which the notice was published has been achieved, and this information has been confirmed by the source National Central Bureau or international entity; or

(b) if this request or alert is linked to one or several other requests or alerts whose purpose has been achieved and without which it cannot be maintained; or

(c) the notice no longer meets the conditions for publishing a notice; or

(d) the National Central Bureau or international entity that requested the notice obtains data allowing it to carry out the required action but has not taken

\footnotetext{
167 Lemon (2019).

168 Lemon (2019).

169 For a comprehensive study on the matter, see: Calcara (2018).

170 Calcara (2019b).

171 To expand on that, the duty lies on the requesting country to ensure: '... (a) the quality and lawfulness of the data it provides in support of its diffusion; (b) that its diffusion complies with the general conditions for recording data; (c) that the data are of interest for the purposes of international police cooperation; (d) that its request complies with INTERPOL's rules, specifically with Articles 2(1) and 3 of the Constitution, as well as with the obligations imposed on the requesting entity under international law...'. RPD art 99.

172 Calcara (2019b).
} 
any steps to this end and, after being consulted, has not provided reasonable grounds for its lack of action.

It can be noted how Article 81(3, c), being an open-ended provision, allows the General Secretariat to intervene with a certain degree of discretion.

Concerning diffusions, the General Secretariat can intervene by enacting the procedure regulated in Article 128 RPD:

Article 128: Examination procedure

(1) Data are, a priori, considered to be accurate and relevant when entered by a National Central Bureau, a national entity or an international entity into the INTERPOL Information System and recorded in a police database of the Organization.

(2) If a doubt arises regarding compliance with the conditions for data processing, including cases where data have been processed by a national entity, the General Secretariat shall consult the National Central Bureau concerned in order to obtain clarifications or supplementary data which may remove the doubt. The General Secretariat shall also consult any international entity if there is any doubt over compliance with the conditions for processing data.

(3) The General Secretariat shall take any other appropriate steps to ensure that these conditions have actually been met.

(4) The examination procedure shall be deemed closed if the General Secretariat concludes that the processing of data:

(a) complies with the present Rules and validates the recording of data;

(b) does not comply with the present Rules and decides to correct the data processing or to delete the data.

The procedure can be performed on diffusions, because while they are circulated directly by NCBs to other selected NCBs, they are also subsequently recorded in INTERPOL's databases. ${ }^{173}$

Additionally, the legal framework of INTERPOL provides its members with the possibility of seeking settlement for disputes concerning the application of the RPD. ${ }^{174}$

Article 135: Settlement of disputes

(1) Disputes that arise in connection with the application of the present Rules should be solved by concerted consultation. If this fails, the matter may be submitted to the Executive Committee and, if necessary, to the General Assembly.

\footnotetext{
173 See INTERPOL (2020g).

174 Martha (2010a).
} 
(2) All national entities shall be represented in the settlement of disputes by their National Central Bureaus. ${ }^{175}$

While seemingly unrelated, this procedure can, and has been, used by members of INTERPOL to challenge notices issued at the request of other members. ${ }^{176}$ The main issue with the system of Article 135 is that in all its phases, it is more of an exercise in political strength rather than in legal reasoning. ${ }^{177}$ So much so that the final step of the process consists of a vote of the General Assembly.

Further, according to Articles 17(5), 131 (1) and 131 (3) of the RPD, INTERPOL can ban a state from using its information system. ${ }^{178}$ This is by far the most drastic legal safeguard that INTERPOL possesses and it appears that until now the organisation has shied away from implementing it. ${ }^{179}$ While it is obvious that these protosanctions are only meant to be used in extrema ratio, up to now they have never been triggered, even in the face of extreme abuse of the notices and diffusions systems. ${ }^{180}$

For the purpose of expanding the number and quality of its own legal safeguards, since 2008, INTERPOL has enlisted the service of an external independent body called the Commission for the Control of INTERPOL's Files. ${ }^{181}$ The creation of the Commission can be seen as INTERPOL's answer to the growing demand by the international community for international organisations to create alternative and effective remedies for individuals affected by their acts. ${ }^{182}$ The Commission has been extensively developed up until recent years, leading to the adoption of the new Statute CCF by the General Assembly in 2016. ${ }^{183}$ The main functions of the Commission are listed in INTERPOL's Constitution, and they include ensuring 'that the processing of personal information by the Organization is in compliance with the regulations the Organization establishes in this matter, ${ }^{184}$ and the processing of 'requests concerning the information contained in the Organization's files.' 185 As such, the Commission acts as an appeal body for those individuals who are the subjects of INTERPOL's notices and diffusions and wish to argue against the appropriateness or lawfulness of their existence and/or the content. ${ }^{186}$ It also acts as a body for those individuals wishing to know whether their information is stored in INTERPOL's database. ${ }^{187}$ 
The procedure for challenging or requesting information is regulated in Articles 29-42 of the Statute CCF. Individuals have the option to request a revision of the decision of the Commission in limited circumstances such as 'the discovery of facts which could have led the Requests Chamber to a different conclusion if that fact had been known at the time at which the request was being processed. ${ }^{, 188}$

Unfortunately, the Commission has been heavily criticised for several reasons. For one, aside the narrow possibility of obtaining a revision, individuals cannot appeal the decisions of the Commission. ${ }^{189}$ Additionally, there seems to be general lack of transparency in how it applies the rules. ${ }^{190}$ Further, NCBs appear at times to be reluctant in complying with the decisions. ${ }^{191}$ Lastly, there is the issue whether the Commission might decide or be compelled in not disclosing information to the applicant due to the reasons mentioned in Article 35 (3) of the Statute CCF:

The communication of information may be restricted at the decision of the Requests Chamber, on its own initiative or at the request of the source of data, the General Secretariat or the applicant, for one or more of the following reasons:

(a) To protect public or national security or to prevent crime;

(b) To protect the confidentiality of an investigation or prosecution;

(c) To protect the rights and freedoms of the applicant or third parties;

(d) To enable the Commission or the Organization to properly discharge their duties.

The aforementioned issues make the process of appeal cumbersome, uncertain, and perhaps insufficient as a safeguard against cases of misuses.

At last, it should be considered that part of the blame for the misuse of INTERPOL's system may rest on the behaviour or actions of INTERPOL itself. Being an intergovernmental organisation and enjoying immunity, it is extremely complicated for individuals to lay claims against INTERPOL in front of domestic courts. ${ }^{192}$ Due to the previously mentioned series of agreements between INTERPOL and France concerning the immunity of INTERPOL, national courts or tribunals do not have jurisdiction and cannot intervene in cases related to notices, diffusions, or data processed through the organisation. ${ }^{193}$ Hence, in instances where INTERPOL is to any extent responsible of wrongful action, the Commission is de facto the main proto-judicial body available for individuals to seek some sort of appeal or regress. Questions should be raised, whether the Commission is adequate to cover this delicate role.

\footnotetext{
188 Statute CCF art 42.

189 Fair Trials (2018).

190 European Parliament (2019).

191 Fair Trials (2018).

192 Ling (2010b), and Sheptycki (2017b).

193 European Parliament (2019).
} 


\section{Discussion}

Throughout the previous chapters, it was presented how INTERPOL has become an avenue for certain authoritarian countries to persecute dissidents and members of the media, mainly to protect their own status quo. ${ }^{194}$ It was highlighted how the way the systems of notices and diffusions are structured and applied has indeed contributed to facilitating this type of abuse. While INTERPOL has developed several legal safeguards throughout the years to address the pitfalls of its own modus operandi, ${ }^{195}$ the safeguards of the organisation can effectively correct only ex post cases of misuse, by for instance allowing individuals subject of cooperation to appeal to the $\mathrm{CCF}$, or by allowing countries to settle disputes among each other inside the organisation. The legal safeguards of INTERPOL appear to be largely inadequate to prevent cases of misuse. ${ }^{196}$ For example, concerning the system of notices, the main preventative legal safeguard is the legal review prior to the issue of red notices. Even this type of a more thorough review stands very little chance of being fruitful ${ }^{197}$ whenever countries forge evidence to back up fictional legal documents, which is evident in Khadzhiev v. Bulgaria (2014).

The root of the ineffectiveness in preventing the circulation of fraudulent requests for cooperation is the fact that INTERPOL does not have the power to thoroughly assess the quality of the criminal justice systems of its own member countries or the modalities of production of the relevant legal documents. ${ }^{198}$ Evidently, what INTERPOL calls 'legal review' of red notices, can only be a mere 'quality' review, limited for instance to a superficial assessment of the coherence of the evidence in relation to the alleged charges mentioned in the notice proposals, or the appropriateness of the judicial documents attached. ${ }^{199}$ In short, INTERPOL can only ascertain whether the form of the legal documents provided by the NCBs appear to be on point, but abstains from judging the substance.

INTERPOL's lack of power to perform proper supervision is a direct consequence of Article 3 of INTERPOL's Constitution and its current interpretation, ${ }^{200}$ which was briefly examined previously. The purpose of Article 3 is not only limited to ascribe the range of activities to be undertaken by the organisation, but it constraints INTERPOL into rigorous principles of neutrality and independence whenever it needs to interact with various international actors. ${ }^{201}$ These absolute characteristics of INTERPOL's neutrality and independence are well inscribed in the DNA of the organisation, being enshrined in INTERPOL's legal framework since $1956 .{ }^{202}$

\footnotetext{
194 Lemon (2019).

195 Ling (2010b).

196 Calcara (2018).

197 Calcara (2018).

198 Calcara (2018).

199 Calcara (2018).

200 Gottlieb (2011).

201 Gottlieb (2011).

202 Further, the need to be bounded by these principles has also been reaffirmed in recent years by INTERPOL itself, particularly in a resolution enacted by the General Assembly in 2006: INTERPOL 'Statement to Reaffirm the Independence and political Neutrality of Interpol' Res AG-2006-RES-04 (19-
} 
The choice of binding itself to these principles was to a certain extent a matter of survival for the organisation. To uphold global security, it has been undoubtedly convenient for INTERPOL to keep an equally detached approach whenever interacting with the various $\mathrm{NCBs}$, regardless of their commitment to conduct police cooperation in good faith. ${ }^{203}$ INTERPOL is cognisant of the everlasting risk of how indisposing and potentially losing involvement of certain countries in the organisation's activities can favour the growth of criminal havens, and thusly increase the amount of transnational crime worldwide. ${ }^{204}$

By promoting a system which facilitates indiscriminate cooperation among countries instead of a prudent approach mindful of the rights of individuals, INTERPOL has, whether willingly or unwillingly, taken a stance on how to balance the issue of security against procedural justice on a global level. ${ }^{205}$ Similar conclusions were reached very recently by the Standing Committee, acting on behalf of the Parliamentary Assembly of the Council of Europe, when adopting Resolution $2315 .^{206}$ In the resolution, the member countries of the Council of Europe are called upon to set an 'example of good cooperation', by 'making use of their influence within Interpol to support the implementation of further improvements so that Interpol fully respects human rights and the rule of law whilst remaining an effective tool for international police co-operation.' 207

\section{Results: Answering the Questions}

All of the above considered, it can be argued that by adopting its own modus operandi, INTERPOL has gone beyond its own original mandate. ${ }^{208}$ If the relevant part of Article 2 is taken into account, INTERPOL is defined essentially as a mere

\footnotetext{
Footnote 202 (continued)

22 September 2006). The resolution is available online at:

https://www.interpol.int/content/download/6083/file/GA-2006-75-RES-04-Statement\%20to\%20Rea ffirm $\% 20$ the $\% 20$ Independence $\% 20$ and $\% 20$ political $\% 20$ Neutrality $\% 20$ of $\% 20$ Interpol.pdf $\quad$ (accessed 3 August 2020). The significance of the resolution was highlighted also by INTERPOL. INTERPOL (2013).

203 Calcara (2018).

204 Calcara (2018).

205 It should be pointed out how the clash between human rights protection and fight against crime is definitely not a novelty. Relevantly, 'Why bother with rights when safety is at risk?' was the provocative title that Andrew Ashworth chose to give to the first chapter of 'Human Rights, Serious Crime and Criminal Procedure'. In this chapter, Ashworth highlighted two distinct ideologies, the first one being the promotion of human rights, the second one the struggle against serious crime. See: Ashworth (2002). See also: Bottoms and Tankebe (2017).

206 Council of Europe 'Interpol reform and extradition proceedings: building trust by fighting abuse Resolution' Res 2315 (29 November 2019). The text is available online at:

http://assembly.coe.int/nw/xml/XRef/Xref-DocDetails-EN.asp?FileID=28303\&lang=EN (accessed 3 August 2020).

207 Council of Europe 'Interpol reform and extradition proceedings: building trust by fighting abuse Resolution' Res 2315 (29 November 2019).

208 On the issue concerning the discrepancies between the mandates and the actual roles of international police cooperation organisations, it is possible to see Gerspacher (2005).
} 
aider of cooperation, as its functions are 'to ensure and promote the widest possible mutual assistance between all criminal police authorities.' However, with the way the system of red notices is structured and implemented, the organisation has created, perhaps inadvertently, a proto-system of judicial cooperation. Such a jump in competence can be difficult to reconcile even with a wide interpretation of the doctrine of implied powers of international organisations. ${ }^{209}$ To expand on that, whenever documents are published by INTERPOL by way of red notices, they automatically achieve an international recognition, which often tramples the ordinary safeguards and mechanisms in place in the criminal justice systems of many countries. $^{210}$ Indeed, INTERPOL has created an unbalanced system, as once data is attached to a red notice, it acquires an unjustified presumption of legality which, even if successfully rebuked in one domestic court of its members, remains unaltered for the other countries that automatically enforce red notices. ${ }^{211}$ In short, whenever INTERPOL issue a red notice, whether on its own initiative or following the request of a NCB, it de facto decides if an arrest warrant should be considered as enforceable for, in a reductive estimation, at least 60 countries. $^{212}$

Returning to the original questions posed by this article: Does INTERPOL have the legal authority to be the one in charge of finding a balance between security and procedural justice? If so, on what legal basis, and to what extent? The answer from a theoretical point of view should be a simple no. ${ }^{213}$ Yet, cognisant of the emerging theories in developing areas such as global constitutionalism ${ }^{214}$ and the paradoxes of international law in general, ${ }^{215}$ other signs point to a positive answer.

As previously discussed, INTERPOL has gained a sort of customary recognition as an intergovernmental organisation, the same process of progressive legalisation could perhaps be inferred for its atypical role in the international scene as well. This can be validated, for instance, by the fact that many international instruments, treaties, and agreements recognise INTERPOL as a legitimate tool for circulating various types of judicial requests. ${ }^{216}$ More importantly, this can be validated by the fact that one-third of its members automatically enforce its red notices and diffusions. ${ }^{217}$ This can be both source and evidence of the recognition by states of the authority of INTERPOL on the international scene.

\footnotetext{
209 For more on the doctrine of implied powers of international organisations see: Klabbers (2005).

210 Savino (2010) and Calcara (2018).

211 Savino (2010).

212 Langille and Mégret (2018).

213 This is in line with the vision of scholars such as Sheptycki, who affirms how: 'Interpol is but one element of a vast transnational legal order that has no democratic basis and which needs to be progressively uncovered through piecemeal empirical case studies.' See Sheptycki (2017b).

214 Wiener et al. (2012).

215 Klabbers et al. (2011).

216 Savino (2010).

217 Langille and Mégret (2018).
} 


\section{Prospects for the Future}

INTERPOL has been under intense scrutiny in the past decade. The organisation has developed a modus operandi which appears to be tailored to warrant security at the expense of the procedural rights of individuals subject to cooperation. ${ }^{218}$ As the need for cooperation on criminal matters has been steadily increasing, it would be naïve and counterproductive to demand at this moment in time a drastic correction of this modus operandi. Several changes have been made to the internal safeguards in recent years, ${ }^{219}$ and more seem to be planned. ${ }^{220}$ However, due to the neutrality of INTERPOL, it is unlikely that the organisation could legally be empowered to assess a priori the lawfulness of the requests for police cooperation coming from the NCBs. For this reason, what INTERPOL calls legal review of red notices, will probably continue to be merely a quality review.

What should be demanded is for the members of INTERPOL to adopt a more cautious approach when enforcing red notices or diffusions. This could be achieved through additional parallel legal means both on the international front, such as resolution 2315 of the Council of Europe, and on the domestic ones. While the problem might be global, a part of the solutions could still be local.

Additionally, it is undeniable that INTERPOL should also be more proactive in spotting repeated instances of abuse by certain countries, and enforce whenever necessary the proto-system of sanctions devised in Articles 17(5), 131 (1) and 131 (3) RPD. ${ }^{221}$

\section{Conclusion}

Following a thorough examination of the most famous tools of INTERPOL, the red notices and diffusions, this article has illustrated how INTERPOL has created and perfected throughout its existence a system which constantly favours relentless cooperation among countries at the expense of a prudent approach mindful of the rights of individuals. Indeed, in its current state, INTERPOL remains an invaluable tool for transnational policing, ${ }^{222}$ while being an easy target for those authoritarian countries wishing to exert their influence and expand their reach well beyond their domestic jurisdictions. ${ }^{223}$

In this article, it was argued that INTERPOL, being also the creator and the administrator of this system, has taken a stance on how to balance the issue of security against procedural justice on a global level, regardless of whether this has been

\footnotetext{
${ }^{218}$ Savino (2010).

${ }^{219}$ Ling (2010b), Martha (2010a), and Calcara (2018).

220 The intention has been manifested clearly by the organisation in recent times. See INTERPOL (2019).

${ }^{221}$ Calcara (2018).

${ }^{222}$ Sweet (2010).

${ }^{223}$ Lemon (2019).
} 
done willingly or unwillingly. Further, there is also a case for claiming that INTERPOL has, inconspicuously to many, already evolved from being an organisation promoting police cooperation into a proto-judicial institution with discretional powers and extensive reach, without being properly equipped to fulfil such a delicate role.

Thusly, the questions which were initially posed Does INTERPOL have the legal authority to be the one in charge of finding a balance between security and procedural justice? If so, on what legal basis, and to what extent? remain more relevant than ever. Unfortunately, they also appear to elude a definite answer. However, this is expected. As in the pioneering work of Wiener et al. on Global Constitutionalism, it was stated: 'global constitutionalism grapples with the consequences of globalisation as a process that perforates national/state borders, thus undermining familiar roots of legitimacy and calling for new forms of checks and balance. ${ }^{224}$ It is frustrating, and probably futile, to dwell at large on the source of legitimacy of certain choices or acts performed by an international organisation. Instead, it is still necessary to seek for better solutions, mindful of the need to protect the rights of those individuals suffering the consequences of the same acts.

Funding Open access funding provided by University of Eastern Finland (UEF) including Kuopio University Hospital.

\section{Compliance with Ethical Standards}

Conflict of interest The corresponding author states that there is no conflict of interest.

Open Access This article is licensed under a Creative Commons Attribution 4.0 International License, which permits use, sharing, adaptation, distribution and reproduction in any medium or format, as long as you give appropriate credit to the original author(s) and the source, provide a link to the Creative Commons licence, and indicate if changes were made. The images or other third party material in this article are included in the article's Creative Commons licence, unless indicated otherwise in a credit line to the material. If material is not included in the article's Creative Commons licence and your intended use is not permitted by statutory regulation or exceeds the permitted use, you will need to obtain permission directly from the copyright holder. To view a copy of this licence, visit http://creativecommons.org/licen ses/by/4.0/.

\section{References}

Abbott, John, and Dale Sheehan. 2013. The INTERPOL Approach to Tackling Match Fixing in Football. In Match-fixing in international sports: Existing processes, law enforcement, and prevention strategies, Haberfeld, Maria R., and Dale Sheehan, 263-287. Springer.

Anderson, Malcom. 1989. Policing the World: Interpol and the Politics of International Police Co-operation. Oxford: Clarendon Press.

Andreas, Peter, and Ethan Avram Nadelmann. 2006. Policing the Globe: Criminalization and Crime Control in International Relations. New York: Oxford University Press.

Ashworth, Andrew. 2002. Human Rights, Serious Crime, and Criminal Procedure. London: Sweet \& Maxwell.

224 Wiener et al. $(2012,11)$. 
BBC. 2018. Putin critic Bill Browder freed after brief arrest in Spain https://www.bbc.com/news/world -europe-44301072.

Barnett, Michael, and Liv Coleman. 2005. Designing police: Interpol and the study of change in international organizations. International Studies Quarterly 49 (4): 593-619.

Bassiouni, M.Cherif. 2014. International extradition: United States law and practice. Oxford: Oxford University Press.

Bigo, Didier. 2000. Liaison Officers in Europe: New Officers in the European Security Field. In Issues in Transnational Policing, ed. James Sheptycki. Abingdon: Routledge.

Boister, Neil. 2018. An Introduction to Transnational Criminal Law. Oxford: Oxford University Press.

Bossard, Andre. 1988. Interpol and Law Enforcement: Response to Transnational Crime. Police Studies: The International Review of Police Development 11: 177.

Both, Charles R. 2002. International Police Force or Tool for Harassment of Human Rights Defenders and Political Adversaries: Interpol's Rift with the Human Rights Community. ILSA Journal of International \& Comparative Law 8 (2): 357-362.

Bottoms, Anthony E., and Justice Tankebe. 2017. Police Legitimacy and the Authority of the State. In Criminal Law and the Authority of the State, ed. Du Bois-Pedain, Antje, Magnus Ulväng, and Petter Asp. Oxford: Hart Publishing.

Bowling, Ben. 2009. Transnational policing: the globalization thesis, a typology and a research agenda. Policing A Journal of Policy and Practice 3 (2): 149-160.

Bowling, Ben. 2010. Policing the Caribbean: Transnational Security Cooperation in Practice. New York: Oxford University Press.

Bromund, Ted. 2019a. Interpol CCF's Latest Annual Report Highlights Fundamental Flaw in The System. Forbes https://www.forbes.com/sites/tedbromund/2019/03/31/interpol-ccfs-latest-annual-repor t-highlights-fundamental-flaw-in-the-system/\#185e9b043a11.

Bromund, Ted. 2019b. Russia Requests Interpol Action On Bill Browder, For Seventh Time. Forbes https ://www.forbes.com/sites/tedbromund/2019/04/30/russia-requests-interpol-action-on-bill-browderfor-seventh-time/\#646609d3392e.

Calcara, Giulio. 2013. Role of INTERPOL and Europol in the Fight against Cybercrime, with Particular Reference to the Sexual Exploitation of Children Online and Child Pornography. Masaryk University Journal of Law and Technology 7: 19-33.

Calcara, Giulio. 2018. Preventing the Misuse of INTERPOL: A Study on the Legal Safeguards of the Organization. Nordic Journal of International Law 87 (1): 56-78.

Calcara, Giulio. 2019a. Rethinking Legal Research on Matters of International Police Cooperation: Issues, Methods and Raison d'Être. Liverpool Law Review 40 (2): 95-111.

Calcara, Giulio. 2019b. INTERPOL's Rules on the Processing of Data. Oxford International Organizations (OXIO) 441.

Calcara, Giulio. 2020. A transnational police network co-operating up to the limits of the law: examination of the origin of INTERPOL. Transnational Legal Theory: 1-28.

Cameron-Waller, Stuart. 2008. 'Interpol: A global service provider. In Combating International Crime: the longer arm of the law, ed. Steven David Brown, 63-78. Abingdon: Routledge.

Cassese, Antonio. 2013. Cassese's international criminal law. Oxford: Oxford University Press.

de Hert, Paul, and Juraj Sajfert. 2018. Police, privacy and data protection from a comparative legal perspective. In Comparative Policing from a Legal Perspective, ed. Boer de Monica. Broadheath: Edward Elgar.

Deflem, Mathieu. 2002a. Policing World Society: Historical Foundations of International Police Cooperation. New York: Oxford University Press.

Deflem, Mathieu. 2002b. The Logic of Nazification: The Case of the International Criminal Police Commission "Interpol”. International Journal of Comparative Sociology 43 (1): 21-44.

Deflem, Mathieu. 2005. International Police Cooperation-History. In Encyclopedia of Criminology, ed. Richard A. Wright and J.Mitchell Miller, 795-798. New York: Routledge.

Deflem, Mathieu. 2006. Global rule of law or global rule of law enforcement? International police cooperation and counter-terrorism. The Annals of the American Academy of Political and Social Science 603: 240-251.

Deflem, Mathieu. 2008. Interpol. In The Oxford Encyclopedia of the Modern World, ed. Peter N. Stearns, 198-199. New York: Oxford University Press.

Deflem, Mathieu. 2010. The policing of terrorism: Organizational and global perspectives. New York: Routledge. 
Deflem, Mathieu. 2016. Interpol. In The Encyclopedia of Crime and Punishment, ed. Wesley G. Jennings, 788-791. London: Wiley-Blackwell.

European Parliament -Directorate-General for External Policies. 2019. Misuse of Interpol's Red Notices and impact on human rights - recent developments https://www.europarl.europa.eu/RegData/etudes/ STUD/2019/603472/EXPO_STU(2019)603472_EN.pdf.

Fair Trials. 2013. Strengthening respect for human rights, strengthening INTERPOL www.fairtrials.org/ wp-content/uploads/Strengthening-respect-for-human-rights-strengthening-INTERPOL4.pdf.

Fair Trials. 2018. Dismantling the tools of oppression Ending the misuse of INTERPOL https://fairtrials .org/publication/dismantling-tools-oppression-1.

Fair Trials. 2020. INTERPOL. https://fairtrials.org/campaign/interpol.

Firestone, Tom, and Kerry Contini. 2018. The Global Magnitsky Act. Criminal Law Forum 29 (4): $617-628$.

Fooner, Michael. 1989. Interpol: Issues in World Crime and International Criminal Justice. New York: Plenum Press.

Gerspacher, Nadia. 2005. The Roles of International Police Cooperation Organizations-Beyond Mandates, toward Unintended Roles. European Journal of Crime, Criminal Law and Criminal Justice 13: 413-434.

Gerspacher, Nadia. 2008. The History of International Police Cooperation: A 150-Year Evolution in Trends and Approaches. Global Crime 9 (1-2): 169-184.

Gerspacher, Nadia, and Veronique Pujas. 2013. International Police Organizations: The Missing Link to Effective Cooperation. In International Police Cooperation: Emerging Issues, Theory and Practice, ed. Lemieux Frédéric, 241-259. New York: Routledge.

Gottlieb, Yaron. 2011. Article 3 of Interpol's Constitution: Balancing International Police Cooperation with the Prohibition on Engaging in Political, Military, Religious, or Racial Activities. Florida Journal of International Law 23: 135.

Higgins, David, and Rob White. 2016. Collaboration at the Front Line: INTERPOL and NGOs in the Same NEST. In Environmental crime and collaborative state intervention, ed. Rob White and Grant Pink, 101-116. New York: Palgrave Macmillan.

Hurd, Ian. 2018. International Organizations: Politics, Law, Practice. Cambridge: Cambridge University Press.

INTERPOL. 2013. REPOSITORY OF PRACTICE: Application of Article 3 of INTERPOL's Constitution in the context of the processing of information via INTERPOL's channels https://www.interpol. int/content/download/12626/file/article-3-ENG-february-2013.pdf.

INTERPOL. 2017. Global Policing Goals. https://www.interpol.int/Who-we-are/Strategy/Global-Polic ing-Goals.

INTERPOL. 2019. INTERPOL reviews its rules for the international exchange of criminal data https:// www.interpol.int/News-and-Events/News/2019/INTERPOL-reviews-its-rules-for-the-internationalexchange-of-criminal-data.

INTERPOL. 2020a. What is INTERPOL? https://www.interpol.int/Who-we-are/What-is-INTERPOL.

INTERPOL. 2020b. Key Dates. https://www.interpol.int/Who-we-are/Our-history/Key-dates.

INTERPOL. 2020c. Legal Documents. https://www.interpol.int/Who-we-are/Legal-framework/Legal -documents.

INTERPOL. 2020d. General Secretariat. https://www.interpol.int/Who-we-are/General-Secretariat.

INTERPOL. 2020e. Databases https://www.interpol.int/How-we-work/Databases.

INTERPOL. 2020f. About Notices https://www.interpol.int/How-we-work/Notices/About-Notices.

INTERPOL. 2020 g. International Notices system https://www.interpol.int/content/download/625/file/ GI-02_2018-03_EN_LR.pdf.

Joutsen, Matti. 2014. International Instruments on Cooperation in Responding to Transnational Crime. In The Handbook of Transnational Crime and Justice, ed. Philip Reichel and Jay Albanese, 255-274. Thousand Oaks: Sage.

Kind, Karl-Heinz. 2011. The role of Interpol in the fight against the illicit trafficking in cultural property. In Crime in the Art and Antiquities World Illegal Trafficking in Cultural Property, ed. Stefano Manacorda and Duncan Chappell, 175-181. New York: Springer.

Klabbers, Jan. 2005. The life and times of the law of international organizations. In International organizations, ed. Jan Klabbers, 151-181. London: Routledge.

Klabbers, Jan, Anne Peters, and Geir Ulfstein. 2011. The constitutionalization of international law. Oxford: Oxford University Press. 
Klabbers, Jan. 2015. An introduction to international organizations law. Cambridge: Cambridge University Press.

Klabbers, Jan. 2017. International Law. New York: Cambridge University Press.

Langille, Nicola, and Frédéric Mégret. 2018. Red Notices and transnational police practices. In International Practices of Criminal Justice, ed. Mikkel Jarle Christensen and Ron Levi, 108-130. New York: Routledge.

Lemon, Edward. 2019. Weaponizing Interpol. Journal of Democracy 30 (2): 15-29.

Ling, Cheah Wui. 2010a. Mapping Interpol's Evolution: Functional Expansion and the Move to Legalization. Policing A Journal of Policy and Practice 4 (1): 28-37.

Ling, Cheah Wui. 2010b. Policing Interpol: The Commission for the Control of Interpol's Files and the Right to a Remedy. International Organizations Law Review 7 (2): 375-404.

Marino, Nina, and Reed Grantham. 2015. Wanted by Interpol: Strategic Thinking about Red Notices, Diffusions, and Extradition. Criminal Justice 30 (3): 4-11.

Martha, Rutsel Silvestre J. 2010a. The Legal Foundations of Interpol. Oxford: Hart Publishing.

Martha, Rutsel Silvestre J. 2010b. Challenging Acts of INTERPOL in Domestic Courts. In Challenging Acts of International Organizations Before National Courts, ed. August Reinisch. Oxford: Oxford University Press.

Sandler, Todd, Daniel G. Arce, and Walter Enders. 2011. An evaluation of Interpol's cooperative-based counterterrorism linkages. The Journal of Law and Economics 54 (1): 79-110.

Savino, Mario. 2010. Global Administrative Law Meets Soft Powers: The Uncomfortable Case of Interpol Red Notices. New York University Journal of International Law and Politics 43: 263-336.

Schöndorf-Haubold, Bettina. 2010. The administration of information in international administrative law-the example of Interpol. In The Exercise of Public Authority by International Institutions, ed. Armin von Bogdandy, 229-267. Berlin: Springer.

Sheehan, Dale L. 2012. Interpol: An International Perspective on Police Training and Development. In Police Organization and Training: Innovations in Research and Practice, ed. Maria R. Haberfeld, Curtis A. Clarke, and Dale L. Sheehan, 169-178. New York: Springer.

Sheptycki, James. 2004. The Accountability of Transnational Policing Institutions: The Strange Case of Interpol. Canadian Journal of Law and Society/La Revue Canadienne Droit et Société 19 (1): 107-134.

Sheptycki, James. 2017a. Brand Interpol. In Trust in International Police and Justice Cooperation, ed. Saskia Hufnagel and Carole McCartney. Oxford: Hart Publishing.

Sheptycki, James. 2017b. Transnational Organization, Transnational Law and the Ambiguity of Interpol in a World Ruled with Law. Brill Research Perspectives in Transnational Crime 2-3: 65-86.

Stalcup, Meg. 2013. Interpol and the Emergence of Global Policing. In Policing and Contemporary Governance: The Anthropology of Police in Practice, ed. William Garriott, 231-261. New York: Palgrave Macmillan.

Sweet, O.C.David. 2010. INTERPOL DVI best-practice standards-An overview. Forensic Science International 201 (1-3): 18-21.

Tinsley, Alex. 2017. 'Echoes of Kadi: Reforms to Internal Remedies at INTERPOL. EJIL: Talk! Blog of the European Journal of International Law https:/www.ejiltalk.org/echoes-of-kadi-reforms-to-inter nal-remedies-at-interpol/.

Tully, James, Jeffrey L. Dunoff, Anthony F. Lang, Mattias Kumm, and Antje Wiener. 2016. Introducing global integral constitutionalism. Global Constitutionalism 5 (1): 1-15.

Ugelvik, Synnøve. 2019. Police Cooperation and Sovereignty in the EU: Norway's Lessons for Europe. London, New York: Routledge Press.

Wellens, Karel. 2002. Remedies Against International Organisations. New York: Cambridge University Press.

Wiener, Antje, Anthony F. Lang, James Tully, Miguel Poiares Maduro, and Mattias Kumm. 2012. Global constitutionalism: Human rights, democracy and the rule of law. Global Constitutionalism 1 (1): $1-15$.

Publisher's Note Springer Nature remains neutral with regard to jurisdictional claims in published maps and institutional affiliations. 